\title{
Porencephalic cyst and late onset brief psychotic disorder
}

\author{
Onur Cemal Noyan, ${ }^{1}$ Celal Şalçini, ${ }^{2}$ Birim Sungu Talu, ${ }^{2}$ Gul Eryilmaz ${ }^{2}$
}

${ }^{1}$ Uskudar University, İstanbul, Uskudar, Turkey

${ }^{2}$ Department of Neurology, Uskudar University, İstanbul, Turkey

\section{Correspondence to} Dr Onur Cemal Noyan, onurnoyan@hotmail.com

Accepted 20 March 2016

\section{CrossMark}

To cite: Noyan $O C$, Şalçini C, Talu BS, et al. $B M J$ Case Rep Published online: [please include Day Month Year] doi:10.1136/ bcr-2016-215098

\section{DESCRIPTION}

We present the first psychotic attack of a 43 -year-old woman who was married for 20 years and had a daughter. The patient had no previous psychiatric or neurological history. She had no drug and no family psychiatric history. The patient had suddenly started suspecting her husband' of infidelity and checking his personal belongings and mobile phone. Sleep disorder, paranoid ideation and irritability were prominent during this period. A problem with her daughter changing schools because of poor educational performance was the only triggering event. Her symptoms started at the time. On mental state examination, the patient was tired-looking and self-care was fair, whereas cooperation and orientation were full. She expressed referential and paranoid delusions about her family. Her attitude was subjectively anxious and suspicious but objectively blunted and she lacked insight about her condition. No perceptual disorders were detected. Family members reported that her personality was irritable and nervous as compared to her childhood demeanour. Only anaemia was detected whereas all other metabolic and haematological tests were normal. No pathologies were detected in the EEG and ECG scans. Her MRI scan demonstrated an extensive porencephalic cyst in the right medial frontal lobe with mild mass effect on the parenchyma (figure 1). Physical and neurological examinations were normal except for the mild anaemia and an extensive porencephalic cyst. Surgical intervention has not been advised by the specialist. The patient was diagnosed with late onset brief psychotic disorder ${ }^{1}$ after detailed evaluation. Oral olanzapine $10 \mathrm{mg}$ was started consistent with previous reports. ${ }^{2}$ At the third week's visit, the paranoid delusions and irritability showed significant improvement.
Porencephaly is a rare disorder of the central nervous system and involves a cyst or a cavity filled with cerebrospinal fluid in the brain's parenchyma. These cysts may be congenital or acquired. Prenatal and postnatally acquired cysts may be due to a number of causes including haemorrhage afterbirth, local damage from ischaemia or traumatic brain injuries. Clinical manifestations such as paresis, seizures, mental retardation, learning disability and psychiatric symptoms from porencephalic cysts may differ according to localisation. ${ }^{3}$

There are only a few case reports of porencephaly and psychosis associations in the literature. Porencephaly may contribute to the development of psychosis, especially if located in the prefrontal and medial temporal lobe of the brain. ${ }^{2}$ This case differs from previous case reports with late diagnosis of porencephalic cysts.

In the present case, the porencephalic cyst was associated with brief psychosis in the presence of stress. Cyst presence in the right frontal lobe might explain the difficulty in handling stress and also might be associated with late onset psychosis.

\section{Learning points}

Porencephalic cyst is a rare disorder and clinical manifestation of the porencephaly may be asymptomatic.

- Porencephaly may contribute to the development of psychosis.

- Neuroimaging is suggested in all patients with late onset psychosis.

Twitter Follow Onur Noyan at @iasonur 
Contributors OCN designed the article and drafted the text. CS selected appropriate images for the article and contributed to writing. GE and BST revised the text for important intellectual content. All the authors approved the final submitted version.

Competing interests None declared.

Patient consent Obtained.

Provenance and peer review Not commissioned; externally peer reviewed.

\section{REFERENCES}

1 Diagnostic and Statistical Manual of Mental Disorders, 5th edition (DSM 5). Washington DC, American Psychiatric Association, 2013.

2 Douzenis A, Rizos EN, Papadopoulou A, et al. Porencephaly and psychosis: a case report and review of the literature. BMC Psychiatry 2010;10:19.

3 Ho SS, Kuzniesky RI, Gilliam F, et al. Congenital porencephaly: MR features and relationship to hippocampal sclerosis. AJNR Am I Neuroradiol 1998;19:135-41.

Copyright 2016 BMJ Publishing Group. All rights reserved. For permission to reuse any of this content visit http://group.bmj.com/group/rights-licensing/permissions.

BMJ Case Report Fellows may re-use this article for personal use and teaching without any further permission.

Become a Fellow of BMJ Case Reports today and you can:

- Submit as many cases as you like

- Enjoy fast sympathetic peer review and rapid publication of accepted articles

- Access all the published articles

- Re-use any of the published material for personal use and teaching without further permission

For information on Institutional Fellowships contact consortiasales@bmjgroup.com

Visit casereports.bmj.com for more articles like this and to become a Fellow 